\title{
Apuntes para pensar los estudios geoculturales y el pensamiento nacional y popular: conexiones entre Raúl Scalabrini Ortiz y Rodolfo Kusch. Peronismo y muchedumbre *
}

\author{
Notes to think about geocultural studies and national and popular \\ thought: connections between Raúl Scalabrini Ortiz and Rodolfo Kusch. \\ Peronism and the crowd
}

\author{
Por: Ighina, Domingo \\ Universidad Nacional de Córdoba \\ Córdoba, Argentina \\ dcmighina@gmail.com
}

Código ORCID: https://orcid.org/0000-0001-6954-6480

Fecha de recepción: 25/03/2021

Fecha de aprobación: 25/05/2021

DOI: http://dx.doi.org/10.30972/nvt.1715356

\begin{abstract}
* El texto se vincula con el proyecto "Muchedumbre y desborde: la configuración de lo popular como negación en el ensayo y la narrativa de los espacios geoculturales del Cono Sur entre 1950 y 2015", Aprobado por SECYT - UNC y radicado en el Centro de investigaciones de la Facultad de Filosofía y Humanidades “María Saleme de Burnichón”, UNC. Período 2018-2022. Director: Dr. Domingo Ighina.

"Domingo Ighina, licenciado y doctor en Letras Modernas por la Universidad Nacional de Córdoba (UNC). Profesor Adjunto por concurso, a cargo de la materia Pensamiento Latinoamericano de la Facultad de Filosofía y Humanidades (FFyH) de la UNC. Investigador en el Centro de investigaciones de la FFFyH, donde dirige equipos de investigación desde 2012. Docente de posgrado en las universidades de Argentina, Brasil y España. Algunas de sus publicaciones: La brasa bajo la ceniza. La fraternidad en el pensamiento de la integración latinoamericana. Un recorrido (2012); "Ver con los ojos cerrados. Crisis de las ontologías nacionales criollas, geoculturas y fagocitación" (2016) y El otro lado de lo dicho. Pueblo y multitudes en la Argentina del Cono Sur (dir.)(2017). Forma parte de la Red Universitaria de estudios de la fraternidad (RUEF) y es miembro de comités de revistas especializadas en estudios sobre cultura y literatura latinoamericanas de Argentina, Brasil y Chile. Domingo Ighina, licenciado y doctor en Letras Modernas por la Universidad Nacional de Córdoba (UNC). Profesor Adjunto por concurso, a cargo de la materia Pensamiento Latinoamericano de la Facultad de Filosofía y Humanidades (FFyH) de la UNC. Investigador en el Centro de investigaciones de la $\mathrm{FFFyH}$, donde dirige equipos de investigación desde 2012. Docente de posgrado en las universidades de Argentina, Brasil y España. Algunas de sus publicaciones: La brasa bajo la ceniza. La fraternidad en el pensamiento de la integración latinoamericana. Un recorrido (2012); "Ver con los ojos cerrados. Crisis de las ontologías nacionales criollas, geoculturas y fagocitación" (2016) y El otro lado de lo dicho. Pueblo y multitudes en la Argentina del Cono Sur (dir.)(2017). Forma parte de la Red Universitaria de estudios de la fraternidad (RUEF) y es miembro de comités de revistas especializadas en estudios sobre cultura y literatura latinoamericanas de Argentina, Brasil y Chile.
\end{abstract}




\section{Domingo Ighina}

\section{Resumen}

Si bien muchos intelectuales latinoamericanos, durante gran parte del siglo pasado y en lo que va del presente, han intentado reformular el conocimiento ofrecido por la modernidad noratlántica, efectuando un análisis crítico del modo en que su reverso -la colonialidad- actuó en los procesos de occidentalización de nuestra subcontinente, la academia ha desvinculado las propuestas de los intelectuales de "posición nacional" en el Cono Sur de las de los estudios críticos de la geopolítica del conocimiento. Por otra parte, la recuperación de la perspectiva geocultural inaugurada por Kusch por parte de filósofos y pensadores ligados a los estudios de la geopolítica del conocimiento, como parte de una relectura de la filosofía de la liberación, permite ahora establecer con certeza un puente entre el conjunto de un pensar descolonial con el pensamiento nacional y popular.

El presente trabajo intenta vincular el llamado "pensamiento nacional y popular" con los estudios geoculturales basados en la propuesta filosófica de Rodolfo Kusch. Con breves entradas a algunas categorías de este filósofo argentino y al pensamiento de Raúl Scalabrini Ortiz, se indaga la posibilidad de comprender al peronismo y la muchedumbre como "entrancias" al pensamiento popular y relación con lo nacional en el Cono Sur.

Se tratará aquí entonces de relacionar las tendencias más relevantes de la "matriz de pensamiento nacional y popular" -según Alcira Argumedo-, con las perspectivas geoculturales del pensamiento latinoamericano, y ofrecer un aporte para completar su panorama en América Latina en general y el Cono Sur en particular.

Aunque lo desarrollado solo indague someramente las propuestas de Scalabrini Ortiz y Kusch, el trabajo se presenta como una serie de apuntes para establecer las conexiones necesarias para completar el panorama del pensamiento latinoamericano y decolonial y sus desafíos actuales.

Palabras clave: pensamiento nacional - estudios geoculturales- Kusch - Scalabrini Ortiz - peronismo/muchedumbre. 
Apuntes para pensar los estudios geoculturales y el pensamiento nacional y popular: conexiones entre Raúl Scalabrini Ortiz y Rodolfo Kusch. Peronismo y muchedumbre

\section{Abstract}

Although many Latin American intellectuals, have attempted to reformulate the knowledge offered by North Atlantic modernity during most of last century and the current one, carrying out a critical analysis of the way in which its reverse - coloniality acted in the Westernization processes of our subcontinent, the academy has decoupled the proposals of the intellectuals of "national position" in the Southern Cone from those of the critical studies of the geopolitics of knowledge. On the other hand the recovery of the geocultural perspective inaugurated by Kusch by philosophers and thinkers linked to the studies of the geopolitics of knowledge, as part of a rereading of the philosophy of liberation, now makes it possible to establish with certainty a link between an ensemble of decolonial thinking with national and popular thinking.

The present work attempts to relate the so-called "national and popular thought" with geocultural studies based on the philosophical proposal of Rodolfo Kusch. The possibility of understanding the Peronism and the crowd as "entrances" to popular thought and its relationship with the national in the Southern Cone is inquired into with brief entries to some categories of this Argentinian philosopher and the thought of Raúl Scalabrini Ortiz.

Hence, this is an attempt to relate the most relevant trends of the "matrix of national and popular thought" -according to Alcira Argumedo-, with the geocultural perspectives of the Latin American thought, and offer a contribution to complete its panorama not only in Latin America in general (and) but also in the Southern Cone in particular.

Although what has been developed only briefly investigates the proposals of Scalabrini Ortiz and Kusch, the work is presented as a series of notes to establish the necessary connections to complete the panorama of the Latin American and decolonial thought and its current challenges.

Keywords: national thought - geocultural studies - Kusch - Scalabrini Ortiz Peronism/crowd. 


\section{Domingo Ighina}

\section{Cómo citar este artículo:}

APA: Ighina, D. (2021). Universidad y universalidad: aportes de la opción decolonial al estudio de políticas universitarias para la inclusión de estudiantes indígenas. Nuevo Itinerario, 17 (1), 226-259.

\section{Introducción}

Desde el comienzo de la existencia independiente de los estados latinoamericanos el lugar epistemológico de la producción de conocimiento ha sido por demás debatido. La posibilidad de construir perspectivas intelectuales críticas "dentro de las propias culturas latinoamericanas" ha provocado discusiones de alcance continental. Por ejemplo, las opuestas concepciones de Juan Bautista Alberdi y Andrés Bello muestran un conflictivo trato con la metrópoli europea en relación al conocimiento y su «utilidad» para las sociedades americanas.

Cuando el tucumano Alberdi propone: "...la América practica lo que piensa la Europa. Se deja ver bien claramente que el rol de la América en los trabajos actuales de la civilización del mundo es del todo positivo y de aplicación" (Alberdi, 1988, p. 95), reclama prudencia epistemológica a los nacientes intelectuales latinoamericanos. Tal prudencia es demandada en tanto se convierte en garantía política, en seguridad de no contradecir las premisas de los proyectos civilizatorios europeos. Es decir: aplicar lo que piensa Europa implicaba incluir el país naciente en la Filosofía de la Historia -en el sentido de "gran relato histórico"- con que los principales estados europeos occidentales justificaban su riqueza y su dominio mundial. Así una actitud de mera aplicación de las teorías y conceptos de Europa aseguraba el avance de las sociedades americanas hacia el lugar privilegiado donde se encontraban los estados noratlánticos.

En cambio Andrés Bello, desde su encumbrada situación en Chile a mediados del siglo XIX, planteaba -casi como lema- "Independencia del pensamiento... Esa es la primera filosofía que debemos aprender de Europa"(Bello, 1957, p. 249) ${ }^{1}$. Postulaba un

\footnotetext{
${ }^{1}$ Agregaba Bello: No olvidemos que el hombre chileno de la independencia, el hombre que sirve de asunto a nuestra historia y nuestra filosofía peculiar, no es el hombre francés ni el 
Apuntes para pensar los estudios geoculturales y el pensamiento nacional y popular: conexiones entre Raúl Scalabrini Ortiz y Rodolfo Kusch. Peronismo y muchedumbre

"pensamiento propio" para "sacudirnos las cadenas". No era un rechazo del conocimiento europeo, sino, desde una visión política diferente a la del argentino, entender que la producción de saberes debe responder a la "humanidad bajo ciertas formas especiales"; es decir a las necesidades de los sujetos que habitan América Latina. Como propone Arturo Ardao:

El obligante tema latinoamericano, "lo latinoamericano», constituye un objeto privilegiado para la filosofía latinoamericana. La propia filosofía europea, habitualmente considerada arquetipo de universalidad, ha hecho también de «lo europeo» un objeto filosófico -privilegiado para ella- como cuando Nietzche se encara con el «nihilismo europeo», o Husserl con la «crisis de la ciencia europea», o Jaspers con el «ser de Europa». Pero la condición de «latinoamericana» de la filosofía latinoamericana no resulta de una temática específica a la que necesariamente se circunscriba o deba circunscribirse. Resulta de la condición latinoamericana de los sujetos que la cultivan, en tanto integrantes de una comunidad histórica con su característica tradición de cultura y su consiguiente tonalidad espiritual (Ardao, 1987, pp. 87 y 88$)$.

De este modo el saber se desprende de su colonialidad ${ }^{2}$ en tanto responde a los intereses de conocimiento de las comunidades históricas heterogéneas llamadas latinoamericanas. Ejercer una práctica histórica en el trabajo intelectual resulta, si se pretende realmente desarrollar un conocimiento situado, inevitable. Esto no debe limitar el trabajo del intelectual a un papel de mero instrumento interesado de saber. Si bien todo conocimiento es político, no puede, sin embargo, sustraerse a una lectura lo más objetiva posible de su objeto, porque el objeto dado informa:

El conocimiento no es otra cosa que la relación del sujeto que quiere conocer, con el objeto que debe ser conocido. Casi más propio sería decir: la resultante de la combinación de un sujeto con un objeto (Ortiz Pereyra, 1984, p.93).

anglosajón, ni el normando, ni el godo, ni el árabe. Tiene espíritu propio, sus facciones propias, sus instintos peculiares (Bello, 1957, p. 249).

${ }^{2}$ Colonialidad en el sentido de colonialidad del poder propuesto por el sociólogo peruano Aníbal Quijano para caracterizar un patrón de dominación global propio del sistema-mundo moderno/capitalista originado con el colonialismo europeo a principios del siglo XVI. Cfr. QUINTERO, Pablo, 2010 "Notas sobre la teoría de la colonialidad del poder y la estructuración de la sociedad en América Latina". 
Manuel Ortiz Pereyra -el autor de la cita anterior- no ignora que ninguno de los dos elementos de la relación de conocimiento se dan de modo prescindente de su ubicación, es decir de su situación geográfica, cultural e histórica. En esto consiste el punto de vista para Ortiz Pereyra, y su variabilidad permite un conocimiento no axiomático, situado. Como había señalado José Martí (1975) "En el periódico, en la cátedra, en la academia, debe llevarse adelante el estudio de los factores reales del país" (Martí, 1975, p.18).

Desde esta perspectiva es imposible aceptar la validez de categorías universales, sin más, como son las de "pensamiento", "nacional" o "muchedumbre". Sin duda resulta operativo partir desde una concepción general de tales categorías, pero estas primeras definiciones sólo importarán un principio analítico a desmontar y reformular de acuerdo al trabajo realizado sobre el corpus determinado. Porque desde la elaboración conceptual se establece un modelo para leer los fenómenos históricos y culturales y puede este modelo ser aplicado de modo mecánico, y resultar entonces inepto para el estudio de determinada sociedad.

Enfatizamos en estas líneas la relaciones posibles entre dos planteos situados del pensamiento en América Latina: por un lado el Ilamado convencionalmente pensamiento nacional y popular -entendido aquí como una matriz de pensamiento- y los estudios geoculturales, que aún partiendo de aquella matriz, buscan actualizar poner en acto- una lectura de la matriz de pensamiento nacional y de los estudios geoculturales como modo de leer los fenómenos de las culturas en América Latina. En este artículo en particular tantearemos ese vínculo a partir de las miradas que sobre el peronismo y las muchedumbres desarrollaron Raúl Scalabrini Ortiz y Rodolfo Kusch, ambos pensadores argentinos ligados a la matriz de pensamiento nacional y popular. Definiremos someramente los conceptos de matriz de pensamiento y de estudios geoculturales, pero limitados a hechos parciales, en tanto que propios de Argentina, que podrán en estudios posteriores ampliarse al Cono Sur y al subcontinente latinoamericano, sucesivamente; como diría Arturo Jauretche (1967) "Sólo se trata de lograr algunas conclusiones, algunos atisbos, para ir aprendiendo la verdad, según nosotros y para nosotros" (p.44). 
Apuntes para pensar los estudios geoculturales y el pensamiento nacional y popular: conexiones entre Raúl Scalabrini Ortiz y Rodolfo Kusch. Peronismo y muchedumbre

La decisión de abordar los conceptos que importan a la historia y las culturas latinoamericanas desde una perspectiva situada implica considerarlos como categorías que deben ser leídas de un modo total. Es decir, leerlos como unidades integradas por propuestas intelectuales más o menos distinguibles que pueden entenderse como teóricas -por ejemplo: la concepción del poder, del individuo, de la cultura, de la nación, de la región en la historia de las ideas y las culturas latinoamericanas-, e históricas -las configuraciones que efectivamente asumen en un lugar y en un momento dados las propuestas teóricas que encierran los conceptos en cuestión-.

Esta doble mirada sobre las categorías con las que se trabaja, y sobre las que se trabaja, exige operar con elementos provenientes de diversas disciplinas de las ciencias sociales y humanas, como la filosofía, la historiografía, la sociología, la literatura y las que requiera el objeto de estudio.

Este enfoque global sobre nuestro objeto puede ser mejor comprendido si recuperamos el concepto de «matriz de pensamiento» desarrollado por Alcira Argumedo:

...denominamos matriz teórico-política a la articulación de un conjunto de categorías y valores constitutivos, que forman la trama lógico-conceptual y establecen los fundamentos de una determinada corriente de pensamiento. Dentro de las coordenadas impuestas por esa articulación conceptual fundante se procesan las distintas vertientes internas como expresiones o modos particulares de desarrollo teórico. Estas vertientes constituyen ramificaciones de un tronco común y reconocen una misma matriz, no obstante sus múltiples matices, sus características particulares, sus eventuales contradicciones o los grados de refinamiento y actualización alcanzados por cada una de ellas (Argumedo, 1996, p.79).

La matriz de pensamiento, tal como la propone Argumedo, nos permite abordar el llamado pensamiento nacional sobre todo en Argentina -como parte del Cono Sur en este trabajo ${ }^{3}$ - como una compleja unidad epistemológica, que a pesar de

\footnotetext{
${ }^{3}$ El Cono Sur se presenta como una categoría nueva -no va más allá de la década de 1940- sin supuestas esencias que la soporten ni proyectos hegemónicos que la propicien. Es más bien un lugar común, al que todos acuden y del que no puede decirse demasiado, pero que guarda ostensiblemente la posibilidad de generar nuevas lecturas para un nuevo tiempo. Además el
} 
sus evidentes contradicciones, genera un campo de lecturas afines sobre cultura, filosofía, literatura, y política. Una matriz de pensamiento agrupa conceptualmente un conjunto muy diverso de propuestas que sin embargo coinciden en promover una redefinición de las relaciones sociales a partir de una premisa y una consecuencia. La premisa consiste en considerar que la fuente de legitimación de América Latina, por ejemplo, se encuentra fuera de la exclusiva voluntad de las personas que la componen y la consecuencia es que entonces se pretenderá, lógicamente, arbitrariamente reconfigurar América Latina, sin considerar la situación histórica concreta de la formas de sociabilidad humana en cuestión. Estas premisa y consecuencia sufrirán redefiniciones según la vertiente que emerja en el entramado de la matriz de pensamiento.

Por eso es que metodológicamente una matriz de pensamiento, si bien puede ser presentada como una unidad, sólo puede ser analizada a partir de sus vertientes, pues sobre ellas actúan factores históricos, externos a las formulaciones puramente teóricas -o así presentadas- de la misma matriz. De este modo esta categoría se expresa mediante diversas configuraciones discursivas, el ensayo entre ellas, que se articulan con las propuestas teórico-políticas y ofrecen el corpus textual sobre el que un estudio histórico trabaja.

Si una matriz de pensamiento debe ser postulada como una unidad y aprehendida históricamente a través de sus configuraciones discursivas, esto supone que el concepto forjado permite no sólo ver la diversidad de vertientes, sino también "las líneas de continuidad histórica de determinadas corrientes de pensamiento, vinculadas con la recuperación explícita o implícita de concepciones y valores fundantes que se reproducen en las distintas vertientes o actualizaciones desarrolladas a partir de un tronco común" (Argumedo, 1996, p.84).

Cono Sur es una construcción territorial no plenamente asumida por las academias ajenas a ese espacio, basta con consultar su definición en el DRAE. Es, conceptualmente hablando, una categoría dispuesta al debate y la construcción y a partir de la cual enfocar de un modo nuevo los problemas de las regiones, del territorio, de los sectores populares, de los estados y de la integración; de las culturas, en definitiva. Una categoría macro-regional que evita la amplia mirada latinoamericana y permite una focalización menos extensa. 
Apuntes para pensar los estudios geoculturales y el pensamiento nacional y popular: conexiones entre Raúl Scalabrini Ortiz y Rodolfo Kusch. Peronismo y muchedumbre

Así una matriz de pensamiento puede también presentarse, a pesar de la relativa diversidad que esconde, como una continuidad y observar más que rupturas de pensamiento, continuidades, permanencias de concepciones culturales, filosóficas y políticas. En definitiva las matrices de pensamiento son, como sostiene Argumedo, expresiones de conflictos sociales, políticos, económicos y culturales y tienden a incidir en los procesos de las sociedades.

Esas expresiones pueden tematizarse, es decir manifestarse en figuras reiteradas que muestran la visión del mundo de aquellos que han forjado y sostenido una matriz de pensamiento. Esta tematización es, ante todo, una operación intelectual capaz de articular, una y otra vez de modo similar, una respuesta histórica a los conflictivos procesos antes aludidos; es entonces una utilización consciente de ciertas imágenes y configuraciones discursivas. Esta tematización es también un repertorio de ideas y concepciones capaces de adaptarse a diversas situaciones históricas y responder a ciertas demandas hechas, o entrevistas, por los sectores populares ${ }^{4}$, que consideran su propio destino social, individual y comunitario, ligado a la suerte del Estado-nación del que participan y al que pretenden dirigir a partir de la ampliación de participación política para gestionar sus propios intereses, desde opciones que les resulten atractivas. La matriz de pensamiento que tematiza estas opciones, que elabora las ideas y concepciones que pretenden dar cuenta de las demandas de los sectores populares, las llamamos -tal como en la tradición intelectual argentinapensamiento nacional y popular y puede extenderse la denominación, sin cometer errores, a diversas corrientes de ideas del Cono Sur, sobre todo de Uruguay y Paraguay.

\footnotetext{
${ }^{4}$ Elegimos para definir a los sectores populares en el Cono Sur, y específicamente en Argentina, a Leandro Gutiérrez y Luis Alberto Romero, como sectores de la sociedad configurados históricamente, como "una identidad que valoraba la colaboración de miembros de pertenencia social variada y que, reposando sobre la expectativa de mejoramiento individual, confiaba en la actuación del Estado para impulsarla, y apelaba a la justicia social para legitimarla" (Gutiérrez y Romero, 1995, p. 13).

${ }^{5}$ En la ensayística uruguaya pueden considerarse partícipes de este pensamiento Luis Alberto Herrera (1873-1959) -Orígenes de la Guerra Grande, 1941; Alberto Methol Ferré (1929-2009) -El Uruguay como problema, 1967- y Washington Reyes Abadie (1919-2002) - La Banda Oriental, pradera, frontera, puerto, 1966), entre varios. En Paraguay, la elaboración de una historiografía revisionista del siglo XIX fue casi la tarea excluyente de la intelectualidad del siglo XX. Quizás Juan Natalicio González (1897-1966) -El Paraguay eterno, 1935- sea el autor central en esta matriz de pensamiento; sin embargo las circunstancias políticas de este país y la deriva de González hacia postulados filofacistas y el escaso
} 


\section{Domingo Ighina}

Por lo tanto el objeto de la matriz de pensamiento nacional y popular se construye históricamente. Esta condición histórica del objeto ofrece algunas particularidades. Primero, partiendo del a priori colonial ${ }^{6}$, la matriz de pensamiento "nacional y popular" se constituye como una crítica a la situación del país en cuestión, pero entendiendo esta crítica como el reverso de la implantación de la modernidad colonial europea y su crisis contemporánea. De allí, es que la matriz de pensamiento nacional y popular se presenta como una visión de las historias nacionales, en vinculación explícita con la historia de América latina, basada en diversos legados imperiales, al tiempo que se erige en frontera entre esos legados y su situación histórica en América Latina: no es la recuperación de lo no occidental, pero sí la corrupción del absoluto de occidente -en tanto autocracia epistemológica- lo que es central en esta matriz de pensamiento en nuestra América.

Esta matriz, entonces, no implica un conjunto cohesionado ideológica y teóricamente, sino antes bien una definición constante pero histórica de un lugar de enunciación -lugar definido como el de los intereses nacionales y popularescoherente desde la servidumbre y la subalternización de los sectores populares. Es clara la descripción que ofrece Arturo Jauretche:

La expresión "posición nacional" admite bastante latitud, pero entendemos por tal una línea política que obliga a pensar y dirigir el destino del país en vinculación directa

movimiento intelectual en Paraguay durante la dictadura de Alfredo Stroessner -1954 a 1989- ubican a los pensadores paraguayos de manera polémica en la matriz de pensamiento nacional y popular: "Este relativo aislamiento no significa, por otro lado, que en Paraguay no se hayan desarrollado líneas de pensamiento bastante similares al resto de América Latina. Positivismo, arielismo, nacionalismo, cepalismo, renovación socialista, han sido tendencias del pensamiento del Paraguay a lo largo del siglo XX" (Devés, 2006, p. 301).

6 Por a priori colonial se entiende aquí a la condición de "herederos" del legado europeo español, pero también británico e italiano- que vastos sectores de los países del Cono Sur reivindican para sí. Esto implica no sólo la herencia de una lengua, sino también de la base de la organización económica, jurídica y educativa. Sobre tal legado el ejercicio de aplicación que propuso Alberdi, conformó una situación subordinada respecto a las propuestas epistemológicas y políticas europeas y norteamericanas. Esa situación -a la cual Arturo Jauretche llamó "colonización pedagógica"- es lo que determinó “...crear Europa en América trasplantando el árbol y destruyendo al indígena que podía ser obstáculo al mismo para su crecimiento según Europa, y no según América [...] Así el proceso de europeización que se practicó desde 1853 en adelante no consistió en la incorporación a la cultura preexistente de los valores europeos -universales si se quiere-, sino en la derogación lisa y llana de aquélla, lo que fue facilitado por esa identificación del concepto de civilización con el concepto cultura, muy propio del siglo XIX" (Jauretche, 1967, pp. 148 y 149). 
Apuntes para pensar los estudios geoculturales y el pensamiento nacional y popular: conexiones entre Raúl Scalabrini Ortiz y Rodolfo Kusch. Peronismo y muchedumbre

con los intereses de las masas populares, la afirmación de nuestra independencia política ene I orden internacional y la aspiración de una realización económica sin sujeción a intereses imperiales dominantes. Esta posición no es una doctrina, sino el abecé, el planteo elemental y mínimo que requiere la realización de una nacionalidad, es decir la afirmación de su ser. No supone una doctrina económica o social de carácter universalista, por más que no pueda ni deba prescindir de una visión de conjunto en el mundo, ni tampoco una doctrina institucional, pues todas son contingentes al momento histórico y sus condiciones. Esto no excluye la posibilidad del desarrollo de una doctrina nacional o de una doctrina de carácter general a condición de que ésta sea histórica, es decir, que nazca de la naturaleza misma de la nación y se proponga fines acordes con la misma (Jauretche, 2011, pp. 22 y 23).

La extensa cita de Arturo Jauretche nos permite describir con mejor precisión esta matriz de pensamiento. En primer lugar hay en esta una preeminencia de lo nacional, es decir de aquello que abarca una comunidad histórica representada en la nación, o estado-nación. Esto implica una condicionalidad histórica evidente y la subordinación de la matriz toda a objetivos ético-políticos claros: soberanía política y económica -lo que implica cierta institucionalidad acorde a estos objetivos- $y$, como complemento obligatorio, justicia y equidad en la distribución de beneficios entre la población de la nación. La "posición nacional" se identifica con uno de los lemas del Peronismo -una patria justa, libre y soberana-, aunque no se agota en él, en tanto es una posición histórica.

En segundo lugar la matriz de pensamiento nacional debe, como consecuencia evidente, vincular los intereses nacionales con los populares, promoviendo una identidad incuestionable en esta matriz. Así, la definición de sectores populares de Gutiérrez y Romero -dos historiadores difícilmente identificables con la matriz de pensamiento nacional- se torna operativa en tanto la actuación del Estado sucedía en función de otorgar justicia social a estos sectores. Pero podemos advertir un matiz jerarquizante en Jauretche: la posición nacional piensa y dirige el país en relación a los intereses de las masas. Este matiz, que de acuerdo a cada vertiente será apenas perceptible o imperceptible directamente, reserva a la nación una prioridad analítica cuanto menos. Es decir, el análisis de los intereses nacionales - 
su economía, su política, sus instituciones- son elementos primeros de estudios, pero que sin lo popular no podrán ser discernidos apropiadamente. Resulta sutil esta división, pero conduce a debates de espesor contemporáneo cuando diversas miradas sobre el uso de los recursos del Estado, los planteos de desarrollo o buen vivir, la concepciones sobre la naturaleza y el ambiente, entran en colisión a partir de juegos de intereses, que según quién y cómo los enuncie, disocian nación y sectores populares ${ }^{7}$.

En tercer lugar, Jauretche indica con claridad que esta posición nacional es un lugar ético y político inicial, lo que implica que teóricamente es abierta, históricamente contingente, pero siempre emancipatoria.

Queda expuesta que el par nacional y popular con que Argumedo, y una larga tradición de pensadores, define a la matriz en cuestión, puede presentar dificultades de convivencia armónica. $\mathrm{Y}$ es porque el pensamiento nacional en el Cono Sur, no exploró con el mismo énfasis una posibilidad otra de penar desde lo popular, no como objeto, sino como sujeto de conocimiento.

Si bien el Pensamiento nacional y popular, la matriz de pensamiento según planteamos aquí, avanza sobre los efectos nefastos que distintas capas de la Modernidad han tenido sobre los sectores populares: su expoliación y subordinación, no pocas veces las herramientas epistemológicas han surgido del pensamiento crítico que la misma Modernidad ofrecía como disponible. Esto no enfoca el problema solo en los autores que, por ejemplo, han intentado aunar marxismo y pensamiento nacional como variantes de una misma matriz ${ }^{8}$, sino

\footnotetext{
${ }^{7}$ Un ejemplo claro fue la disputa por la carretera del Tipnis que atravesaba el Parque Nacional Isiboro Sécure y que desde 2011 enfrenta al Estado Plurinacional de Bolivia con algunas comunidades indígenas que viven en el parque. La necesidad de la carretera como forma de integración territorial es un viejo planteo del estado boliviano, al que se agrega ahora la exigencia de mejorar las condiciones de vida de los habitantes del lugar -el acceso a centros médicos de complejidad, por ejemplo-. Por otra parte las comunidades indígenas del Tipnis contrarias a la carretera hablan de un radical cambio de vida de sus integrantes por culpa de la obra, y de la destrucción de un bosque de una biodiversidad extraordinaria. Este conflicto afecta también en toda América a las políticas mineras y de extracción de combustibles fósiles, mostrando o negando, una desvinculación entre intereses nacionales o populares, dentro de la matriz de pensamiento nacional y popular.

${ }^{8}$ Cfr. Cooke, J.W. (2011). Peronismo y revolución. Buenos Aires: Colihue; Galeano, E. (2004). Las venas abiertas de América Latina. Buenos Aires: Siglo XXI; Hernández Arregui, J.J. (2004). La formación de la conciencia nacional. Buenos Aires: Peña Lillo-Continente; Ramos, A. (2011). Historia de la nación latinoamericana. Buenos Aires: Continente.
} 
Apuntes para pensar los estudios geoculturales y el pensamiento nacional y popular: conexiones entre Raúl Scalabrini Ortiz y Rodolfo Kusch. Peronismo y muchedumbre

incluso en aquellos han planteado un "modo nacional" de enfrentar este problema ${ }^{9}$.

La propuesta aquí es indagar sobre propuestas, dentro de la matriz del pensamiento nacional y popular, que avancen en viraje epistemológico que supere lo geopolítico y avance sobre lo geocultural.

\section{De geopolítica y geocultura}

Zulma Palermo en Desde la otra orilla. Pensamiento crítico y políticas culturales en América Latina plantea, siguiendo a Aníbal Quijano, que la colonialidad -esa fuerza que produce la "diferencia colonial" que genera un sujeto doblemente fracturado en su identidad, valorado negativamente por el discurso hegemónico que clasifica al mundo según su propio sistema geopolítico- resulta de una "hegemonía eurocéntrica como perspectiva epistemológica" (Quijano, 1997, p. 117). Así la ubicación, el desde dónde, desde donde se lo enuncia resulta en una valoración a priori de lo enunciado, en tanto valor de conocimiento. Si bien Grecia ya no cuenta hace siglos entre las potencias hegemónicas de occidente, su lugar filosofía en tanto conocimiento valioso se convirtió en los cimientos del lugar desde donde el mundo se clasifica y ordena en provecho de la expansión de la Modernidad. Ciertos territorios, y los sujetos que los habitan, son los habilitados para realizar las proposiciones de respaldo o impugnación de esa taxonomía de la Modernidad. Otros, en cambio, son territorios y personas no valiosas, convertidas en meros objetos, cuya localización resulta no central, periférica, y por lo tanto subalternizada.

Así para constituir América Latina, o las naciones del Cono Sur, y romper el lugar del margen, Grecia continúa como centro político del saber entre las élites regionales, e incluso se espera de ese legado el derecho de ejercer sin más la filosofía. No deja de haber allí -aún cuando se considere esto como una apropiación de la herencia europea- una dislocación que obliga a separar al

\footnotetext{
${ }^{9}$ Los títulos de las obras son un índice al respecto: Chávez, F. (1988). Civilización y barbarie en la historia de la cultura argentina. Buenos Aires: Ediciones Los Cohihues; Jauretche, A. (2001). Manual de zonceras argentinas. Buenos Aires: Corregidor; (1984). Ejército y política. La patria grande y la patria chica. Buenos Aires: Peña Lillo editor.
} 
enunciador que pretende conocer y decir algo valioso, con su la mera experiencia de vivir en la periferia. La disputa geopolítica tendrá que ver con la recuperación de memorias no clasificadas o negadas por la Modernidad, mientras se procura introducir pluriversalmente en la configuración del lugar epistemológico al viejo Tahuantinsuhu, a la par que la Antigua Grecia, como ya proponía José Martí en 1891. Se trata de reformular el conocimiento (re)construyendo un lugar de enunciación del intelectual, del que dice:

Posicionarse críticamente desde el "lugar" latinoamericano, desde las particularidades de su propio proceso de formación significa analizar el proyecto occidentalista para revertirlo, buscando las formas de emergencia de las historiasculturas alternativas o marginalizadas tanto por razones de carácter económico como étnico y/o genérico (Palermo, 2005, p. 95).

Así, estudiar la geopolítica del conocimiento permitirá dar cuenta del lugar de poder desde donde se enuncian los saberes, su funcionalidad en la expansión e imposición de la Modernidad y ver la emergencia de nuevos paradigmas otros desde los márgenes de occidente.

La "posición nacional" de Jauretche no está alejada de esta mirada geopolítca del conocimiento, en tanto busca universalidad, sino una funcionalidad política en relación a la nación. Y si esa nación es pensada hegemónicamente fuera de su propia situación histórica, la tarea de la "posición nacional" es pensar desde lo nacional, desde el lugar subalternizado por el saber colonial o imperial: "[las zonceras] a medida que usted vaya leyendo algunas... se irá sorprendiendo...de haberlas oído... y lo que es peor, pensado desde ellas" (Jauretche, 2001, p.12). Desmontar la pedagogía colonialista implica un lugar epistemológico marcado por una crítica a la geopolítica del conocimiento impuesta por la Modernidad.

Por eso la matriz de pensamiento nacional y popular parte desde un planteo claramente geopolítco, particularmente notorio en Arturo Jauretche (1901-1974) y Juan José Hernández Arregui (1913-1974). Al criticar las alianzas que las élites locales tejieron con las colonizaciones ibéricas y con la pedagogía colonial británica, relevo de las primeras, marcan una continuidad histórica de subordinación del estado-nación americano que le impide ser "justo, libre y 
Apuntes para pensar los estudios geoculturales y el pensamiento nacional y popular: conexiones entre Raúl Scalabrini Ortiz y Rodolfo Kusch. Peronismo y muchedumbre

soberano". Indagar sobre la memoria de las rebeldías suscitadas contra esa entente de élites locales (oligarquías en el lenguaje de la "posición nacional") y los diversos coloniales, promoverá una mirada epistemológica geopolíticamente situada que alentará la emancipación intelectual casi como requisito, no como exigencia previa, sino casi simultáneamente, para impugnar y desmontar la colonialidad en América Latina, sobre todo en el Cono Sur.

Palermo, en su libro citado, acompaña su lectura sobre las propuestas críticas de las geopolíticas del conocimiento, describiendo las miradas de los estudios geoculturales latinoamericanos. Los estudios geoculturales, que tienen sus cimientos en la matriz de pensamiento nacional y popular de manera evidente, buscan de qué manera los discursos dislocados de la Modernidad, en tanto se enuncian desde "la marginalidad y la barbarie" -como decía Leopoldo Zea- son corrompidos por el "estar ahí" de los sectores populares que "gestan" los sentidos de los discursos y los textos, lo que les permite negar a quien los niega; vale decir, negar la taxonomía epistemológica de la Modernidad.

...aspiramos a riguroso examen de los semas fundamentales que configuran mensajes latentes, perdidos u olvidados en la contracara de los discursos oficializados. Son intradiscursos cuyas coordenadas invisibles se trazan a partir del único sujeto que siempre está en pie, aún cuando esté acostado, el pueblo como gestor ... de una actividad esencialmente dialógica (más que un antidiscurso, una simple habladuría) nacida del esfuerzo colectivo por formalizar una singularidad que a primera vista se define como desaforada y caótica (Torres Roggero, 1998, pp. 11 y 12).

La postura de Torres, que actualiza la propuesta de Rodolfo Kusch (19221979), cuestiona el saber construido como universal y total desde la Modernidad al igual que las perspectivas geopolíticas pero enfatiza el sujeto cultural que lleva adelante el cuestionamiento. No se trata del intelectual que hace "causa común con los oprimidos de la tierra", otra vez como dice José Martí, sino directamente del oprimido, pero bajo la denominación de pueblo o sujeto popular. Lo que propone Kusch, y con él los estudios geoculturales, es establecer un diálogo a partir de la tarea intelectual con el sujeto popular para desde ese hablar habladuría- dialógico trazar las categorías y los discursos que permitan la 
emancipación de los pueblos en América Latina. Es un paso más allá de la posición nacional de Jauretche porque se trata no solo de atender, sino de convertirse en gestor de las sabidurías populares, de ponerlas en circulación fuera de los sectores que las producen y desde allí formalizar, si fuera posible, un conocimiento que busca el mismo objetivo ético-político.

Claramente la noción de pueblo, y sus derivados semánticos, puede resultar lábil, por lo que Kusch propuso otras categorías que permiten, por un lado, ubicarlo en cierta situacionalidad subjetiva -el concepto de geocultura- y por otro lado que describa de modo inicial la operación de corrupción del episteme colonial -los conceptos de fagocitación y entrancia-.

Rodolfo Kusch entendió por geocultura una categoría que apelmaza la cultura con el espacio, y mediante la cual un grupo reviste de significado su lugar y construye un baluarte de su existencia, desde donde dialoga con otras geoculturas. En todo caso la geocultura implica sujetos culturales siempre en construcción a partir de sus decisiones estratégicas producidas desde una situacionalidad. Así, no habría una esencia, una ontología nacional por ejemplo, o de otro modo un saber universal, sino un conocimiento corruptor de lo imperial, en tanto ese saber se forja en la experiencia de un grupo en un espacio que produce sentidos que dan cuenta de su transformación. No se trata de un saber telúrico, sino de un dinamismo no determinado por el devenir universalizante de occidente. La geocultura es el espacio como lugar de conocimiento. Implica la asunción de culturas surgidas por efecto de la experiencia imperial, pero que no son meros replicantes en tanto buscan el amparo y el equilibrio.

Epistemológicamente, cambiar el eje de discusión en torno a una cultura o culturas nacionales o latinoamericanas, hacia otro eje que hable de geoculturas americanas, exige considerar los contextos vitales y cotidianos donde el pensamiento y los rituales se dan, de modo tal que los sujetos americanos no occidentales, en tanto constructores del sentido del espacio, se convierten en gestores de un saber dialogante que configurará una imagen de sí situada, no ajena a la episteme imperial que los atraviesa en tanto los margina o excluye-, pero no subalterna.

El concepto de unidad geocultural lleva incluso a cuestionar filosóficamente la posibilidad de un saber absoluto al modo como lo propone el pensamiento 
Apuntes para pensar los estudios geoculturales y el pensamiento nacional y popular: conexiones entre Raúl Scalabrini Ortiz y Rodolfo Kusch. Peronismo y muchedumbre

occidental. [...] Si se logra fundar la observación de que todo pensamiento es naturalmente grávido y tiene su suelo, cabría ver en qué medida dicha gravidez crea distintas formas de pensamiento. Quizás se podría ampliar entonces todo lo que se refiere a una antropología del pensamiento en el sentido de no establecer ad hoc un pensamiento así llamado universal, sino de descubrir en la gravidez del pensar [...] (Kusch, 1978, p. 17) $)^{10}$

La negación de la posibilidad de un saber universal, menos aún de uno imperial en tanto no puede destruirse la condición de pensar geoculturalmente, supone una corrosión de la ontología nacional en Argentina y América. Un corrosión que por eso mismo cuestiona los fundamentos políticos de la historia de occidente en América y abre la brecha del reconocimiento de sujetos otros, marginados o excluidos, heterogéneos en tanto geoculturales.

No interesa tanto la postulación por parte de Kusch, como de muchos de los pensadores argentinos del siglo $\mathrm{XX}$, de la existencia de un pueblo homogéneo, sujeto de pensamiento alternativo al imperial, sino más bien la asunción de la exterioridad de la episteme imperial en tanto protagonista de una historia situada. Esa asunción, que por otra parte surge desde la experiencia política de encontrar a esos sujetos en la casa de gobierno, en la Plaza de Mayo, en los resultados electorales, en las huelgas o en las resistencias contra los sistemas de dominación, encuentra en la geocultura la fuente proteica para entender dos movimientos, como describía Martínez Estrada: centrífugo, en tanto es la apertura para el reconocimiento sucesivo y simultáneo de los sujetos otros; centrípeto, en tanto disputa críticamente y con coherencia la epistemología desplegada por el imperio. Esto último en un sentido unificador: la corrupción del absoluto occidental: el progreso y sus instrumentos, la ciencia y la tecnología.

La geocultura presupone entonces una célula cambiante desde donde se construyen sentidos que permiten la intervención de una comunidad en la historia, no sólo en la "gran historia", que para Kusch es la historia de la especie en la tierra, sino, en lo que nos interesa aquí, en la "pequeña historia", es decir en la historia que una

\footnotetext{
${ }^{10} \mathrm{KUSCH}$, Rodolfo: Esbozo de una antropología filosófica americana, Buenos Aires, Castañeda, 1978, página 17.
} 
comunidad se da en el tiempo mensurado por los propios hombres, la historia en el sentido narrativo de los acontecimientos.

Esta dimensión, siempre leída por Kusch como un resultado del hacer de occidente, puede ser reducida al relato teleológico del progreso -resumido en el preámbulo de la Constitución argentina, por ejemplo-, pero también la podemos entender como el diálogo incesante de los espacios geoculturales.

Dos vías nos permiten pensar así. La primera se deduce del hecho de que una geocultura americana está atravesada necesariamente por la presión que ejerce el relato occidental de esa misma pequeña historia. No puede ningún espacio geocultural ignorar, a riesgo de convertirse en un parque temático o museo, que la dinámica de la instituciones de poder también introduce elementos simbólicos que dan sentido a una comunidad. La idea de nación, como construcción de un estado, en la experiencia latinoamericana, se impone como un elemento finalmente apropiado por los sujetos geoculturales para dar sentido a su existencia. Una nación, en definitiva, no es sólo lo que Bartolomé Mitre ${ }^{11}$ y su grupo diseñaron para la Argentina, en nuestro caso, sino también un conjunto de significados seminalmente operativos para la elaboración de autoadscripciones identitarias. Una nación implica un relato fundacional que organiza no pocas prácticas y elabora interpretaciones del futuro de ese grupo. No es raro que una determinada geocultura interprete la nación desde su situacionalidad y se apropie hasta la transformación de conceptos creados para su estandarización. De este modo lo que fue diseñado como instrumento estabilizador de sentidos, a manera de un diccionario, se vuelva, contrariamente, en una operación incesante de balbuceos que sólo se comprenden si se evita la elipsis de "no estar ahí". ¿Quién puede afirmar que categorías clasificatorias y ordenadoras como "nación", "patria", "país", "América", significan lo mismo para todo espacio geocultural americano, y por inclusión, argentino?

Seguramente esta tarea permanente de aprender y desaprender se da a través del de lo que Kusch llamó "entrancias geoculturales". Desde esta perspectiva es

\footnotetext{
${ }^{11}$ Intelectual, político y militar liberal argentino (1821-1906), presidente de la República entre 1862 y 1868. Sus obras más relevantes son Historia de Belgrano y la Independencia argentina (1859/1889) e Historia de San Martín y de la Emancipación americana (1887/1890).
} 
Apuntes para pensar los estudios geoculturales y el pensamiento nacional y popular: conexiones entre Raúl Scalabrini Ortiz y Rodolfo Kusch. Peronismo y muchedumbre

que podemos entendemos porqué el peronismo -como planteamos en la introducción- es un elemento mediante el cual se da la "entrancia geocultural" de la relaciones entre pensamiento y política, entre estética y política. Así también porqué es imposible que se repitan los términos que ese debate tuvo hace cuarenta o más años.

Es claro que tal entrancia se da en un sujeto geocultural por lo que el modo de darse es novedoso, en tanto la geocultura no remite a esencias sino a un estar aquí. Y ese aquí, el espacio geocultural, ha sido marcado por la pequeña historia argentina. Lo que estamos tratando de establecer entonces es que la discusión contemporánea sobre pensamiento y América, entre pensamiento y polítca, se da a través de una serie de "entrancias" que provocan, a la vez que son provocadas. Y el peronismo es una notable "entrancia geocultural" de los últimos cincuenta año para debatir el pensamiento, la literatura, el arte y la política.

Reflexionar y crear una nueva retórica desde esa "entrancia geocultural", importa discutir sobre el supuesto que el peronismo permite asumir: lo popular. Entonces la bisagra del debate entre política y literatura es la/s cultura/s popular/es. Sus modelizaciones en la literatura, en el arte, en el pensamiento, son los balbuceos de los que antes hablamos y lo que permite la actualización -la puesta en acto- de la "entrancia".

\section{Entrancia geocultural}

En Indios, porteños y dioses (1966) Rodolfo Kusch relata un episodio sucedido en un ciudad del altiplano boliviano. A una mujer casi le es arrebatado por un camión el bebé que llevaba en su aguayo. El narrador reacciona como un occidental, socorre a la mujer, insulta a los gritos al camionero y decide ayudar a la mujer a denunciar el incidente. La señora, una indígena, sólo dice "casi me arrastra la huahua" y se va. Esta distancia de respuestas ante el mismo hecho lleva a Kusch a suponer que existe un vacío intercultural entre ambas que no se limita a establecer que una reacción es justa y en defensa de los derechos y la otra sumisa y "subalterna". Kusch trata de explicar 
que la mujer "cree en los dioses" y nada dice -porque Dios o los dioses han salvado a su hijo, o podrían haber matado-, mientras que él no y entonces protesta.

La clave para entender el valor ejemplar de la anécdota pasa por la idea de creencia. Kusch la define de la siguiente manera:

[Es] la prolongación de uno mismo hacia afuera. El objeto de fe es puesto afuera, en medio de la dura realidad. Por eso el indio -porque cree- ve afuera un fenómeno vital, mientras que yo -que no creo- no veo otra cosa que un fenómeno mecánico (Kusch, 1994, p. 25).

Podemos explicarnos entonces que la creencia es el movimiento mediante el cual el mundo exterior se constituye a partir de los sentidos que a sus objetos y representaciones les otorgamos, tanto como individuos como, sobre todo, como comunidad. La creencia permite que la exterioridad entre en mi fe, y cada hecho, objeto o situación serán inteligibles a partir de la verdad global con la que construyo mi existencia. Desde la geocultura entonces el mundo puede ser "entrado", comprendido. Y al ser la entrancia un fenómeno vital, logra una identificación de hecho entre conocer y vivir. Pero se conoce a partir de los objetos y hechos que cobran sentido. Éstos, símbolos o dioses, permiten concretar históricamente la entrancia geocultural, porque identifican vida y conocimiento. No hay un pensamiento causal ni parametrado; no se mide ni divide la "dura realidad". Si se hiciera así el sujeto, ya desprendido de la comunidad en tanto se convierte en una unidad de medición, operaría por saliencia. En ese movimiento son los objetos los que convierten al saber en algo ajeno al hecho de vivir y por lo tanto, separan sujeto y objeto y se da el "fenómeno mecánico" al que alude Kusch, es decir un saber vuelto mecanismo, y por lo tanto universal e imperial.

En Pensamiento indígena y popular en América (1970), Kusch profundiza lo que antes había insinuado, y plantea:

[...] en tanto hay un cómo ha de darse también una visión orgánica de la realidad teñida uniformemente por los sentimientos. Ahí, "todo objeto sigue entrado en la totalidad del mundo y participa de todos los demás con la máxima intimidad", según dice Stern. Por otro lado, en el porqué se da un análisis de la misma realidad con divisiones articuladas, pero con una especial tendencia a ver esas divisiones en forma 
Apuntes para pensar los estudios geoculturales y el pensamiento nacional y popular: conexiones entre Raúl Scalabrini Ortiz y Rodolfo Kusch. Peronismo y muchedumbre

independiente. El objeto, según Stern, en este caso sale de la totalidad del mundo y se independiza (Kusch, 1977, pp. 206-207).

Como correlato de esto Kusch plantea que en Sudamérica -por inclusión el Cono Sur, nos atrevemos a decir- hay una estructura cultural montada sobre un pensar por entrancias, "que personaliza al mundo y destaca la globalidad de éste, porque enfrenta el desgarramiento original entre lo favorable y lo desfavorable y requiere obsesivamente la unidad llevada por un afán de salvación” (Kusch 1977, p. 209).

Desde esta perspectiva podemos plantear que el peronismo no es un simple tema literario o un complejo problema político y sociológico. Esas son perspectivas de "saliencia". De otro modo, entendemos porqué el peronismo es el elemento que comprendido por "entrancia" da cuenta de un saber no parametrado que permite la irrupción de la gran historia en la pequeña historia que logra una segunda identificación: la de fenómeno vital y político, quizás de vida y nación.

Es claro que tal entrancia se da en un sujeto histórico geoculturalmente situado, por lo que el modo de darse es novedoso, en tanto la geocultura no remite a esencias sino a un estar aquí. Y ese aquí, el espacio geocultural, ha sido marcado por la pequeña historia argentina. Lo que estamos tratando de establecer entonces es que la discusión sobre el peronismo y sus representaciones -artísticas, literarias, socialespuede ser leída a través de una serie de "entrancias" que provocan, a la vez que son provocadas. $Y$ el peronismo es a su vez una notable "entrancia geocultural" de los últimos sesenta años para debatir pensamiento, literatura, arte y política en Argentina.

Reflexionar y crear una nueva retórica desde esa "entrancia geocultural" importa discutir sobre el supuesto que el peronismo permite asumir: lo popular. Entonces, es la bisagra del debate entre política y pensamiento es la/s cultura/s popular/es.

Las modelizaciones en de ese fenómeno político-cultural del peronismo a través de la literatura, el arte y el pensamiento, pueden ser entendidos como balbuceos que permiten la actualización -la puesta en acto- de la "entrancia" para los sectores populares, pero también y fundamentalmente, la posibilidad de comprensión -para aquellos grupos explicitan una distancia socio-cognoscitiva respecto de aquellos sectores- de los intereses de las "masas populares". 


\section{Domingo Ighina}

El entrecruzamiento, en la matriz de pensamiento nacional y popular, de la perspectiva que prioriza la discusión sobre la geopolítica del conocimiento y la mirada geocultural, sin duda se da casi desde el comienzo de la "posición nacional", aunque no fuese luego el método más transitado. La obra del ensayista, poeta y narrador, Raúl Scalabrini Ortiz (1898-1957), resulta la piedra de toque para comenzar la tarea de encontrar los puntos de contacto entre estas dos líneas de la misma matriz de pensamiento, que permitan pensar el Cono Sur-América Latina por extensión- por fuera de la colonialidad. Exploremos rápidamente esta complementariedad de perspectivas que propone el autor de El hombre que está solo y espera.

\section{La lectura de Scalabrini Ortiz}

En 1946 Raúl Scalabrini Ortiz publica Los ferrocarriles deben ser del pueblo argentino. En ese texto recupera los argumentos que durante quince años había difundido a favor de la independencia económica argentina y en contra del imperialismo británico. El libro está lleno de datos económicos, de informes estadísticos y de caminos políticos y económicos para alcanzar soberanía para el estado nacional.

Sin embargo escribe un capítulo -central para nuestra argumentación- llamado "Nacimiento de una esperanza". No es un escrito que apunte directamente a la nacionalización de los ferrocarriles sino a tratar de explicar el contexto de posibilidad que puede alcanzar esta iniciativa en la Argentina del año 1946, desde una perspectiva poética y filosófica. Está en este capítulo la famosa descripción del 17 de octubre. Pero nos interesan aquí los fundamentos de esa jornada.

No se dedica Scalabrini a reconstruir la minucia política del año 45. Antes bien relata lo que significaba Perón en los espacios profundos del país:

Todo allí [en el Chaco] es callado y receloso: el árbol, el hombre y el plantígrado que acecha. Pero en los márgenes de lo explorado, en cada lugar en que se reúne la voluntad humana, en los obrajes, en los aserraderos, en los conciertos de conchavo, en las estafetas y estaciones, ya sea en el amplio parlotear que las cañas alimenta; o en el resumido musitar de los extenuados por el trabajo, vibraba insistente, el mismo 
Apuntes para pensar los estudios geoculturales y el pensamiento nacional y popular: conexiones entre Raúl Scalabrini Ortiz y Rodolfo Kusch. Peronismo y muchedumbre

par de sílabas que resumía una esperanza casi tan grande como la selva misma: Perón (Scalabrini, 2008, p. 51).

La nominación de la esperanza con el vocablo Perón no es para el ensayista una constatación de la popularidad del gobernante, sino la conjunción entre la gran historia y la pequeña ${ }^{12}$. Porque si bien Perón es configurado en el relato como la contracara del régimen conservador y fraudulento instaurado desde 1930 en Argentina, es ante todo la esperanza de conjurar el caos y el hambre que sufren los sujetos oprimidos del país. En ese sentido no es raro entonces que describa cómo Perón ya era objeto de culto casi religioso en 1945. Y no lo atribuye a un pretendido atraso evolutivo, que confunde mesianismo con opción política, sino porque es la forma mediante la cual un ministro de un gobierno, y su obra política, se convierten en una entrancia. Esta manera permite a los sujetos geoculturales establecer un diálogo con la pequeña historia y otorgar un sentido de salvación a lo que los ojos occidentales ven como una política social. De allí que Scalabrini entienda entonces a Perón y al peronismo como entrancia que permite hacer de la nación una forma del equilibrio.

La "entrancia geocultural" no es una operación consciente de una comunidad, antes se da un terreno de imponderables, es decir, más a allá de acciones políticas y sociales definidas a priori como modos de volver significativos objetos o discursos. Pero evidentemnte esos gestos de "entrancia" suceden históricamente y afectan el orden social y político de una comunidad. En 1945 irrumpe en Argentina el Ilamado movimiento peronista que provoca un vuelco radical en el modo de hacer política y de concebir la nación. ¿De qué modo esa irrupción supone una entrancia que permita sustraer nación y política fuera del juego de saberes parametrados y coloniales?

Scalabrini avanza aún más y para eso se vale de una idea de muchedumbre que se deja leer desde el movimiento de entrancia. Cuando describe los que marchan por Buenos Aires hacia Plaza de Mayo el 17 de octubre de 1945 a la tarde, muestra una multitud heterogénea -inmigrantes de distintos países, descendientes de españoles y de indígenas y criollos y habitantes de diversas zonas-. Pero resume todos en la

\footnotetext{
${ }^{12}$ Agrega Kusch que la diferencia entre ambas historias -grande y pequeña- se vuelve irremediable porque la gran historia responde a las simples y muy profundas vivencias humanas que persisten, por ejemplo, en las tribus del Amazonas y también en las masas de las grandes ciudades. Es necesario conciliarlas, aunque sea de forma inestable, agregamos.
} 


\section{Domingo Ighina}

"muchedumbre". Este concepto contiene las líneas que venimos desarrollando. Muchedumbre recoge todas las esperanzas heteróclitas de los habitantes oprimidos del país; es también una conciencia superadora de la individualidad y representa lo que él llamó "espíritu de la tierra", un hombre gigantesco dotado de una tensión espiritual que sabe positivamente su inserción en la gran historia y busca también su inserción en la pequeña historia, esa que es protagonizada por los políticos, los economistas, los próceres. Esa muchedumbre -“la más heteróclita que puede la imaginación concebir" escribe Scalabrini- es un principio político vital, pues busca sostener una política y una economía de amparo que la cobije y que, además, mediante su marcha y proclama festiva identifica en los cantos a Perón con una cosa que hace a la patria hermosa y al mismo hombre, ya símbolo o sucedáneo de los dioses, convertirlo en santo -"San Perón"-. Esto hace que tanto el sujeto histórico Perón como lo que emerge con él -el caudillo- se den a manera de una entrancia necesaria para incorporar los elementos de la pequeña historia en la gran historia. El nombre de Perón es para Scalabrini el conjuro que había realizado el milagro de la conjunción de ambas historias: "Eran los hombres que están solos y esperan que iniciaban sus tareas de reivindicación. El espíritu de la tierra estaba presente como nunca creí verlo" (Scalabrini, 2008, p. 56). Así la muchedumbre, devenida en entrancia geocultural en el plano de la nación y su historia, hace del peronismo una creencia, la prolongación de esa muchedumbre en el afuera.

\section{La lectura kuscheana}

Resulta claro que la experiencia peronista, de la cual Kusch no hace referencia explícita en este período, obliga sin dudas a asumir una serie de problemas que parecían no mera contingencia, sino cuestiones raigales cuando de historia y culturas argentinas y latinoamericanas se trata. En La seducción de la Barbarie (1953) ya había tratado algunos elementos centrales de los debates ocurridos una vez derrocado el gobierno constitucional en 1955. 
Apuntes para pensar los estudios geoculturales y el pensamiento nacional y popular: conexiones entre Raúl Scalabrini Ortiz y Rodolfo Kusch. Peronismo y muchedumbre

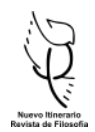

La referencia al caudillo hecha en ese ensayo ubica el temprano texto kuscheano en una discusión política de larga tradición en el país ${ }^{13}$ pero que había adquirido una significación distinta a la luz de la experiencia peronista.

En La seducción de la barbarie en el capítulo IV -“El mestizaje mental o la superación negativa"- Kusch plantea que entre la tierra y la ciudad, entre la realidad y la ficción, se erige el caudillo como equilibrio negativo -es decir, como equilibrio de opuestos que corrompe uno de sus términos en tanto participa de la negación de lo afirmado-. El caudillo encarna una "vitalidad autóctona" que emerge sin doblegar, a diferencia del tirano mestizo, porque no cree en la certeza de la ley de la ciudad y actúa "como un árbol solo", domina a distancia, y puede surgir de esa tierra, crecer, amparar y morir luego, para que, seminalmente, surja otra de sus semillas o raíces del suelo para gestar un árbol nuevo, el mismo. Kusch completa, extrañamente, el párrafo afirmando: "La masa en todo esto no cuenta, porque es silenciosa e inexpresiva, como lo puede ser la fuerza natural antes de informarse" (KUSCH, S/F, p. 53).

Kusch recupera el tema del caudillo que, como vimos, no carecía de tradición. Realiza una lectura que de alguna manera lo pondría en el "bando revisionista" ${ }^{14}$ en

${ }^{13}$ Desde Facundo (1845) el tema/problema del caudillo recorrió fuertemente la discusión política en Argentina. En una suerte de primera formulación del "populismo", el caudillo fue asociado a la Barbarie, en tanto su instrumento ciego y natural -Quiroga para Sarmiento en su libro de 1845- o su constructor artero y artificial -Rosas para el mismo sanjuanino-. Las neurosis en los hombres célebres de la historia argentina (1907, en su versión definitiva) de José María Ramos Mejía, Facundo (1903) de David Peña, son textos precursores, en el feroz marco del Positivismo, en el sentido de convertir un anatema en un problema. El Centenario va a permitir una relectura del caudillo, pero moderada. Es la década del 1930 la que permite la emergencia de un debate histórico que irá recuperando la figura del caudillo, como parte de una memoria colectiva que tiende a cuestionar el poder. Los usos y elaboraciones más o menos facciosos de esa memoria popular y colectiva en torno al caudillo es parcialmente nuestro tema. Bibliografía sobre el caudillo en la matriz de pensamiento nacional y popular: PRIETO, Adolfo (comp.) El rosismo en la literatura argentina (1968), SVAMPA, Maristella: EI dilema argentino: civilización o barbarie (1994), QUATTROCCHI-WOISSON, Diana: Los males de la memoria. Historia y política en la Argentina (1995), IGHINA, Domingo: El libro de los reyes. Ensayo sobre el caudillo en la narrativa de Manuel Gálvez (1998).

${ }^{14}$ Entenderemos aquí por "Revisionismo" a la corriente historiográfica que cuestiona, desde distintas posiciones políticas, la historiografía que en Argentina se llama "oficial", es decir la que fue escolarmente difundida en el calendario festivo -feriados nacionales-, en los libros de enseñanza, pero sobre todo aquella que asentada sobre las premisas de civilización y progreso delineó una teleología de la historia del país. La obra de Bartolomé Mitre sería el paradigma y la fuente de la historia oficial. El Revisionismo en cambio busca recuperar aquello que ha sido 
tanto asocia al caudillo con la "realidad" y escinde su significación de la del dictador latinoamericano, que medra a la sombra de la ficción ciudadana. Hasta aquí Kusch no ingresa a la discusión sobre el punto con argumentos muy novedosos. Pero sin embargo irrumpe con dos afirmaciones que lo sacan de las filas de uno u otro bando. En primer lugar el caudillo no doblega, no impone. Pareciera que el sema más destacado de todo caudillo es su capacidad de conducir, e históricamente de enfrentar, mandar, doblegar al enemigo. De ahí su consideración de fuerza natural -el "tigre" sarmientino- ,o heroica -el héroe homérico de David Peña-. Kusch hace una distinción entre dominar "a distancia" y doblegar. El ejercicio despótico del poder es ajeno al caudillo; no se trata de un militar violento o de un tirano al uso, sino de una fuerza vegetal que "se da" y tiende a proteger, no a transformar o cambiar. Esto se deriva de la inexistencia de tensión dialéctica en América. Los opuestos se concilian, no sin conflicto, y alcanzan un equilibrio, uno de cuyos síntomas es el caudillo.

¿Qué es dominar a distancia? Es una analogía -abundantes en este primer texto kuscheano- que ubica la posibilidad americana como un espacio dado, ajeno a la historia que Europa propone en su acción conquistadora, y presentada simplemente como un "demonismo vegetal" que en el mejor de los casos puede dar vida, amparo, pero ignora la historia en tanto historia de las instituciones o de hechos $u$ hombres relevantes. El caudillo actúa entonces, en el demonismo vegetal de América, casi como el ombú solitario que da sombra y cobijo a la vida en un desierto verde. El caudillo es resultado de la tensión imposible de resolver, ya no sólo entre el bien y el mal, lo fasto y lo nefasto, sino entre la ficción de la ciudad europea y la realidad vegetal del continente. No hay programa en el caudillo ni superación desaforada del demonismo en pos de la ficción dinámica del progreso y la ciudad. El caudillo opera a modo de gestor de una posibilidad de vida, casi de supervivencia. Por eso "abarca toda la ficción". Trasciende el mero hecho de oponerse a la colonialidad o al dominio

negado en la historiografía oficial, o descripto como obstáculo. En un primer momento el Revisionismo se dedicó fuertemente a reivindicar la figura de Juan Manuel de Rosas, para luego, a medida que el debate político del país alcanzaba complejidad, abordar otros problemas y construir, entonces sí, nuevas perspectivas que pretendieron superar el antagonismo de civilización/barbarie. No es posbile agotar en esta nota un fenómeno tan polisémico y heterogéneo, simplemente se quiere encuadrar la lectura. 
Apuntes para pensar los estudios geoculturales y el pensamiento nacional y popular: conexiones entre Raúl Scalabrini Ortiz y Rodolfo Kusch. Peronismo y muchedumbre

oligárquico de la polis y todo lo contamina, todo lo deja en estado de corrupción hedienta. El caudillo no es violento porque piense en matar para gobernar. Tiene la complejidad del Macbeth de Shakespeare: mata, sí, por ambición y control, es un tirano más; pero también desplaza el eje del poder hacia cierto fatalismo que hace que la historia no sea la del orden y la ley, sino un peso de lo absoluto del cual el héroe trágico shakespereano es instrumento indócil pero efectivo. El caudillo, entonces, cumple un destino fatal: impregnar al mundo de la ficción y el progreso de la incredulidad en el determinismo legal que se pretende. El caudillo arruina lo que la ciudad impone, lo corrompe, y es un instrumento de fagocitación ${ }^{15}$.

En esto radica la diferencia con el tirano -que "está en la misma sombra" que la ficción de la ciudad- y no necesariamente será eliminado o expulsado de la ciudad y su historia. En cambio el caudillo sí, porque representa el polo vegetal y distendido de América, es decir la falta de la tensión interna de las relaciones que Europa cree creadora de las cosas. El caudillo es el refugio para vivir sin esa "tensión", para alcanzar un equilibrio de opuestos. Mantiene así vivo "el reverso de América", porque, a su pesar, está sí en el juego tensivo de los opuestos en América: la civilización y la barbarie, el ser y el estar. Puede agotarse porque no se perpetúa en una legalidad que está siempre en manos de la ciudad, pero "existe" como semilla dispuesta a crecer para amparar. Cuando tal cosa hace sufre el embate de la ficción y aunque la pueda dominar, en esa agresión-tensión forma parte de un juego de objetos que lo agoten. Así, el Rosas de "Diálogo de muertos" de Borges podrá afirmar: "Yo no necesité ser valiente. Una lindeza mía, como usted dice, fue lograr que hombres más valientes que yo pelearan y murieran por mí. El valor, es cuestión de aguante; unos aguantan más, y

\footnotetext{
15 “... la aculturación se produce solo en un plano material, como la arquitectura o la vestimenta, en cambio, en otros órdenes pudo haberse producido un proceso inverso, diríamos de fagocitación de lo blanco por lo indígena. Quizá hubo siempre una acción simultánea de los dos procesos pero nuestros ideales de progresismo nos impiden ver a este último. La fagocitación se da en un terreno de imponderables, en aquel margen de inferioridad de todo lo nuestro, aun de elementos aculturados, respecto a lo europeo, ahí donde adquirimos nuestra personalidad nacional, cuando somos netamente argentinos, peruanos, chilenos o bolivianos y también en ese hecho tan evidente de nuestra mala industria o nuestra peor educación pública" (Kusch, 1986, pp. 158 y 159). Fagocitación es la corrupción del absoluto de occidente, de su episteme imperial, en América por parte de los sectores populares y no por una operación de consciente, sino por el mero hecho utilizar ese conocimiento para subsistir. La fagocitación se apropia del conocimiento colonial e imperial, y al mismo tiempo contamina ese mismo saber en América.
} 
otros menos, pero tarde o temprano todos aflojan" (Borges 2011, p. 34). Rosas no escapa a la ficción de ser dictador o tirano -“otros por mí"-, y el riesgo de constituir un sistema de ciudad lo expone a la tensión de la historia. Frente a un Facundo que dice que "[a mí] me tocó guerrear en por las soledades de América, en una tierra pobre, de gauchos pobres. Mi imperio fue de lanzas y de gritos y de arenales y de victorias casi secretas en lugares perdidos", a Rosas "le tocó mandar en la ciudad". Para Borges, en extraña coincidencia con Kusch, la ciudad ejerce también su corrupción al transformar la mera vegetalidad demoníaca de vivir, como la lucha de Facundo, en un sistema de poder para lo cual se debe doblegar. El caudillo, entonces, corre el riesgo de su propia ficción, de ser Rosas -“A mí me basta ser el que soy", le hace decir Borges al final del cuento a Juan Manuel de Rosas, en una afirmación ciudadana digna de la teoría de Rodolfo Kusch- antes que el ignoto pero vital y vegetal Quiroga.

Por otra parte Kusch desliza esta afirmación sobre las masas: "La masa en todo esto no cuenta". Sin dudas una afirmación de este tipo en el contexto del peronismo y en plena puja sobre el papel de las masas en los gobiernos ya entonces comenzados a llamar "populistas", resulta extraño.

Si la masa fuera mero hecho demográfico la afirmación de Kusch sería entendible en tanto ese elemento está fuera de las proposiciones filosóficas del texto. Pero la masa es el elemento en el cual el demonismo vegetal de América se da. La masa, la muchedumbre, la multitud, constituye en tanto "americana" el lugar donde la ficción de la legalidad ciudadana se corrompe y la realidad se manifiesta como hedienta y distendida. Ahora bien si la masa nada tiene que ver, no cuenta, respecto del caudillo, ¿cuál es la relación entre ambos elementos? En primer lugar para Kusch la masa es una fuerza natural sin forma y adquiere cierta posibilidad en el caudillo, por ejemplo. Así la masa es un sustrato que no actúa, sino a través de una semilla o una emanación vegetal. Es "silenciosa e inexpresiva". Aquí hay un problema interesante en Kusch pues desvincula elementos que la tradición intelectual americana relaciona persistentemente y desde distintas perspectivas. ¿Cómo puede darse un caudillo sin masa? ¿Sólo a partir de su vinculación de entramado vegetal? Una afirmación tal, en 
Apuntes para pensar los estudios geoculturales y el pensamiento nacional y popular: conexiones entre Raúl Scalabrini Ortiz y Rodolfo Kusch. Peronismo y muchedumbre

1953, pone en discusión un factor central de la legitimidad peronista, de la legitimidad del caudillo que más explorará geoculturalmente Rodolfo Kusch.

\section{El subsuelo oscuro.}

Oscuramente presentía que el hombre es digno de serlo por lo que calla, no por lo que expone, por lo que sofoca, no por lo que desencadena; por lo que proyecta, no por lo que realiza (SCALABRINI, 2008, p. 235). La cita de Raúl Scalabrini Ortiz, de Tierra sin nada, tierra de profetas (1946), nos orienta en un sentido que parece acercarse al Kusch de La seducción de la barbarie. Primero, el valor de lo callado, de lo sofocado, es decir lo silencioso e inexpresivo, no desencadena ni realiza. Es decir no hace cosas ni provoca causas con sus respectivos efectos. Es decir el hombre scalabriniano no actúa en el plano de los objetos y de las leyes que gobiernan la ciudad. Un acto puede provocar otros, puede haber leyes que expliquen esas relaciones y la cultura se convierte en un entramado legal que da paso a la ficción. Scalabrini "presiente" -un gesto cognitivo desplazado de occidente- oscuramente que el hombre proyecta, lanza hacia adelante, aquello que calla o sofoca. En otros términos el hombre calla la realidad pero la manifiesta en una imagen que lo contiene y lo lanza a una vorágine que sucede sin que ponga necesariamente en juego una afirmación. Lo que proyecta, el símbolo, le permite evitar la afirmación de una ley de correspondencia entre él y lo/el proyect/o/ado. Así el hombre -y su extensión, la masa- proyectará sin que cuente esto como afirmación. El caudillo entonces, a la luz de Scalabrini, afirmará, hará proyecto, pero sin comprometer el silencio germinal de los hombres o las masas. Podremos comprender mejor la afirmación kuscheana de que el caudillo "no alcanza a ser un fin en sí mismo, sólo se hace sentir en tanto se antepone como realidad a la ficción ciudadana, aunque no escape a su propia ficción" (KUSCH, S/F: 54). Entonces la masa no tiene que ver con el caudillo en tanto no se afirma en él, pero proyecta a través suyo la negación del orden ciudadano, negación que es deformidad, caos, barbarie y sinsentido. 


\section{Domingo Ighina}

En el mismo libro Scalabrini incluye una versión de su famosa descripción de la jornada del 17 de octubre de 1945, tal como antes explicitamos. Vale retomar algunos de sus párrafos:

Corría el mes de octubre de 1945, el sol caía a plomo sobre la Plaza de Mayo, cuando inesperadamente enormes columnas de obreros comenzaron a llegar. Venían con su traje de fajina, porque acudían directamente desde sus fábricas y talleres. No era esa muchedumbre un poco envarada que los domingos invade los parques de diversiones con hábitos de burgués barato. Frente a mis ojos desfilaban rostros atezados, brazos membrudos, torsos fornidos, con las greñas al aire y las vestiduras escasas cubiertas de pringues, de restos de brea, de grasas y de aceites. Era la muchedumbre más heteróclita que la imaginación puede concebir. Los rastros de sus orígenes se traslucían en sus fisonomías. Descendientes de meridionales europeos iban junto al rubio de trazos nórdicos y al trigueño de pelo duro en que la sangre de un indio lejano sobrevivía aún (Scalabrini, 2008, p. 245).

La cita nos ubica en el escenario demoníaco fundamental del peronismo: la multitud en proceso de constituirse y emanar su proyecto: Perón. Perón es un caudillo ${ }^{16}$ que proyectará el amparo frente a la ley opresiva y ficticia de la ciudad, sin necesidad de que esa muchedumbre se convierta en una antítesis que la obligue a ser antagonista o polo tensivo. Decir Perón le permite a la masa-muchedumbre negar a quien la niega, pero sin dejar de buscar el equilibrio, el fiel que permita la vida. Proyectar(se) en Perón la salva de decirse o definirse, es decir de cosificarse, y le permite entonces también fagocitar -seguir fagocitando- el determinismo legal de la civilización. La proyección del "subsuelo de la patria sublevado" no es necesariamente una nueva legalidad, sino un momento decisivo de negación de la dominación y la confianza en una nueva posibilidad de amparo.

Ahora bien, para 1953 los gobiernos de Juan Domingo Perón ya no son el caudillo que crece y ampara, no es Quiroga luchando batallas secretas, como imagina Borges. Para cuando Kusch escribe La seducción... los gobiernos peronistas han aprobado una nueva constitución nacional, han promovido la industria nacional al

\footnotetext{
${ }^{16}$ La lectura completa del libro citado y de Los ferrocarriles deben ser del pueblo argentino (1946) dará cuenta de la potencia simbólica y de amparo de Perón para la "masa" a mediados de la década de 1940, según Scalabrini Ortiz.
} 
Apuntes para pensar los estudios geoculturales y el pensamiento nacional y popular: conexiones entre Raúl Scalabrini Ortiz y Rodolfo Kusch. Peronismo y muchedumbre

punto de hablar de la "burguesía nacional"; la CGT -Confederación General del Trabajo- se convierte en la "columna vertebral del movimiento" y las relaciones sociales han cambiado con una multiplicidad de leyes que van del voto femenino a las vacaciones pagas; de la política de salud pública al estatuto del peón de campo. El peronismo ya no es algo que pretenda extinguirse luego de dar frutos, sino que más cerca de Rosas que de Quiroga, se erige como un intento de dominar la ficción y no sucumbir a "su propia ficción".

Kusch deberá responder este devenir de la gran historia en la pequeña historia, según el caudillo se convierte en legalidad de amparo, pero no lo hará de inmediato, aún "Kusch está por hablar, está por soltar la habladuría de su corazón, está por ingresar en el index de los malditos, está por ser declarado hereje y arrojado fuera de la academia" (Torres Roggero, 2016, p. 87). Scalabrini Ortiz, en cambio, ya descubrió que la "economía es un método de auscultación de los pueblos. [...] En sus síntesis numéricas laten, perfectamente presentes, las influencias más sutiles: las confluentes étnicas, las configuraciones geográficas, las variaciones climatéricas, las características psicológicas y hasta la casi inasible pulsación que los pueblos tienen en sus esperanzas cuando menos" (Scalabrini, 1986, p. 9). La pequeña historia es fagocitada por los pueblos y se vuelve parte de la gran historia. Queda como tarea conectar de modo preciso, pero vital, las habladurías "que están creándose mutuamente" (Scalabrini, 2008, p. 242).

Kusch concluye su Esbozo... "la publicidad de un estilo de vida total, que abarque toda la fórmula del estar-siendo no dependerá de una reflexión. Ha de ser siempre una práctica" (Kusch, 1978, p. 145). Es decir, pensar desde los sectores populares implica una práctica, un asumir constante la cotidianidad que se habita, en intersección con la palabra crítica de la colonialidad. Esa intersección, en el Pensamiento Latinoamericano, apenas si está planteada y poco o nada explorada. Las voces y los silencios - como titula Argumedo su ensayo- aún no dan un fruto evidente en el entrecruzamiento entre el pensamiento nacional y la opción descolonial. Si como plantea Mignolo (2016, p. 32) existe una disputa por la matriz colonial que escapa de las manos de sus creadores y el mundo se abre a una disputa entre el control de la 
matriz colonial y la emergencia de aquello que la colonialidad marginó y subalternizó, los estudios geoculturales, y su relación situada y genealógica con el pensamiento nacional del Cono Sur, ofrecen la capacidad de hacer confluir práctica y reflexión crítica de modo histórico. Los cruces de la pequeña y la gran historia son, en definitiva, el objeto de los estudios geoculturales y su capacidad de "localizar la opción descolonial" (Palermo, 2016, p. 43), permitirá articular las voces de los sectores populares en la lucha por su afirmación histórica.

\section{BIBLIOGRAFÍA}

Alberdi, J.B. (2006). Ideas para presidir la confección del curso de filosofía contemporánea en el Colegio de Humanidades. En J. B. Alberdi La cuestión americana (pp. 94-102). Buenos Aires: Grupo Editor Universitario.

Ardao, A. (1987). El latinoamericanismo filosófico de ayer a hoy. En A. Ardao, La inteligencia latinoamericana (pp. 85-98). Montevideo: Universidad de la República.

Argumedo, A. (1996). Los silencios y las voces en América Latina. Notas sobre el pensamiento nacional y popular. Buenos Aires: Ediciones del Pensamiento Nacional.

Bello, A. (1957). Temas de Historia y Geografía en Obras completas, tomo XIX. Caracas: Ministerio de Educación.

Gutiérrez, L. y Romero, L. (1995). Sectores populares, cultura y política. Buenos Aires en la entreguerra. Buenos Aires: Editorial Sudamericana.

Jauretche, A. (1967). Los profetas del odio y la yapa: la colonización pedagógica. Buenos Aires: Peña Lillo ediciones.

(2001). Manual de zonceras argentinas. Buenos Aires: Corregidor. (2011). FORJA y la Década Infame. Buenos Aires: Corregidor.

Kusch, R. (S/F). La seducción de la barbarie. Rosario: Editorial Fundación Ross. (1977). El pensamiento indígena y popular en América. Buenos Aires: Hachette. 
Apuntes para pensar los estudios geoculturales y el pensamiento nacional y popular:

conexiones entre Raúl Scalabrini Ortiz y Rodolfo Kusch. Peronismo y muchedumbre

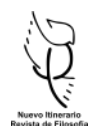

(1978). Esbozo de una antropología filosófica americana. Buenos Aires:

Castañeda.

--------. (1986). América Profunda. Buenos Aires: Bonum.

(1994). Indios, porteños y dioses. Buenos Aires: Secretaría de Cultura de la Nación y Editorial Biblos.

Martí, J. (1975). Nuestra América. En J. Martí. Obras completas tomo 6 (pp.15-23). La Habana: Editorial de Ciencias Sociales.

Mignolo, W. (2016). Más sobre la opción descolonial. En Z. Palermo (comp.) Pensamiento argentino y opción descolonial (pp.17-32). Buenos Aires: Edciones del Signo.

Ortiz Pereira, M. (1984). Reflexiones para aprender a conocer la realidad nacional. En

N. Galasso (ed.), Testimonios del precursor de FORJA; Manuel Ortiz Pereira (pp.93-107). Buenos Aires: Centro Editor de América Latina.

Palermo, Z. (2005). Desde la otra orilla. Pensamiento crítico y políticas culturales en América Latina. Córdoba: Alción.

(2016). Del pensamiento nacional a la opción descolonial: aportes desde el

Cono Sur. En Z. Palermo Pensamiento argentino y opción descolonial (pp. 3344). Buenos Aires: Ediciones del Signo.

Quintero, P. (2010). Notas sobre la teoría de la colonialidad del poder y la estructuración de la sociedad en América Latina. En Papeles de Trabajo 19. Centro de Estudios Interdisciplinarios en Etnolingüística y Antropología SocioCultutal. Recuperado de https://core.ac.uk/download/pdf/61698027.pdf

Scalabrini Ortiz, R. (1986). Política británica en el Río de la Plata. Buenos Aires; Plus Ultra.

(2008). Los ferrocarriles deben ser del pueblo argentino. Rosario:

Editorial Fundación Ross.

(2008). Tierra sin nada, tierra de profetas, Rosario: Editorial

Fundación Ross.

Torres Roggero, J. (1998). Silabario. Silabario, 1, 9-23. 


\section{Domingo Ighina}

(1998). La lectura como práctica histórica. En J. Torres Roggero, La Donosa Barbarie. Córdoba: literatura y cultura. Córdoba: Alción.

(2016). La seducción de la barbarie. Esbozo de una poética geocultural. En J. A. Tasat y J. P. Pérez (coords.) Arte, estética, literatura y teatro en Rodolfo Kusch (pp. 67-87). Buenos Aires: Centro Cultural de la Cooperación y UNTREF. 